\title{
NÃO SEI
}

http://dx.doi.org/10.11606/issn.2175-3180.v13i25p312-313

Mateus Santos de Carvalho ${ }^{\mathrm{I}}$

A agonia de não saber

Mas que chato se eu soubesse

Quero ser o que não fui

Sem saber o que acontece

Num dia, acho que sou

No outro, acho que já fui

Fico indo, voltando

Naquilo que fizeram de mim

Não fui eu que fiz

Não fui eu que quis

Não sou eu que quero

Não sei o que espero

Se me derem a resposta,

Por certo vou duvidar

Vou falar sobre incertezas

E a beleza de não ser

Sobre as vantagens de deixar

E defender o acontecer.

I Universidade do Vale do Rio dos Sinos, São Leopoldo, Rio Grande do Sul, Brasil. 
Recebido em 9 de abril de 2021

Aprovado em 13 de julho de 2021

Mateus Santos de Carvalho

Discente da Universidade do Vale do Rio dos Sinos (UniSinos).

Contato: mateuscarvalhode@gmail.com

A Revista Desassossego utiliza a Licença Creative Commons Attribution que permite o compartilhamento do trabalho com reconhecimento da autoria e publicação inicial neste veículo - Attribution-NonCommercial-NoDerivates 4.0 International (CC BY-NC-ND 4.0) e reconhece que os Autores têm autorização prévia para assumirem contratos adicionais separadamente para distribuição não-exclusiva de versão dos seus trabalhos publicados, desde que fique explicitado o reconhecimento de sua autoria e a publicação inicial nesta revista. 